\title{
粘液中ムコ多糖類の組織学的研究
}

\author{
（第一報） \\ 堀 みどり・間島 雄一・坂倉 康夫・三吉 康郎

\section{Histochemical Identification of Glycoproteins in Mucus Secreting Cells}

\author{
Midori Hori, Yuichi Majima, Yasuo Sakakura and Yasuro Miyoshi \\ (Mie University)
}

Glycoproteins within mucus secreting cells of airway epithelium can be subdivided into two groups, acid and neutral. The acid glycoproteins include sialylated glycoproteins which are either sensitive or resistant to the enzyme sialidase, and sulfated glycoprotein. This study is concerned with the staining of glycoproteins by Alcian Blue at various $\mathrm{pH}$ levels combined with periodic acid-Schiff, as described by Jones and Reid.

Tracheal glands of the mouse, sublingual glands of the rat, and submaxillary glands of the dog were chosen for study because the nature of their glycoproteins is known. In the mouse there is a mixture of neutral and sialidase sensitive sialylated glycoproteins. In the rat only sialidase resistant sialylated glycoproteins are present. In the dog glycoprotein is sulfated. Serial tissue sections of each species were stained with a combination of the Alcian Blue and periodic acid-Schiff techniques. The result proved that the method is useful in identifying these glycoproteins. With Alcian Blue at $\mathrm{pH}+2.6$ all acid glycoproteins stained blue. After sialidase treatment with similar staining, both sialidase resistant and sulfated glycoproteins stained blue. With Alcian Blue at $\mathrm{pH}=1.0$ only sulfated glycoprotein stained blue. With Alcian Blue at $\mathrm{pH}=1.0$ only sulfated glycoprotein stained blue. With this sequence of techniques, the neutral form of glycoprotein failed to stain with Alcian Blue and stained red.

ムコ多糖は, ヒト及び各種動物組織に広く分布し, 組織の形態形成や, 外部からの保護等といっ た重要な機能をむつ. 酸性基の有無により, 酸性ムコ多糖と中性ムコ多糖に大別され, 前者は更 に, カルボキシル基をむつシアル酸ムコ多糖と, 硫酸基をむつ硫酸ムコ多糖とに分けられる. シア ル酸ムコ多糖は, シアリダーゼ感受性のものと, 抵抗性のものを含む. 今回我々は, 乙れら 4 種類 のムコ多糖の存在が既に確かめられている動物組織を用いて, Jones と $\operatorname{Reid}^{1{ }^{21}}$ の異なった pH 下 のアルシアンブルー・P A S 重染色法を施行し, その有用性を確認した. 


\section{実 験 方 法}

\section{一実験動物一}

組織中のムコ多糖は，種及び組織により，特 異性があるとされている3． 本実験において は，存在するムコ多糖が既に同定されている動 物組織を用いた。ママウス気管腺は，主に，中性 ムコ多糖とシアリダーゼ感受性シアル酸ムコ多 糖を産生し4)，ラット舌下腺は，シアリダーゼ 抵抗性シアル酸ムコ多糖を5)，イ又顎下腺は硫 酸ムコ多糖を主に産生する ${ }^{6}$ とされている（表 -1 ).

$\mathrm{C}_{3} \mathrm{H}$ 系マウス（生後 6 週, 雄）の気管, Spraque-Dawley 系ラット（生後 6 週, 雄) の 舌下腺, イヌの顎下腺を, 屠殺直後に採取し,

$0.5 \% \mathrm{C} \mathrm{PC}$ 中性ホルマリンで 24 時間以上固定 後, 上昇アルコール系列にて脱水し, パラフィ ン包埋した. $4 \mu \mathrm{m}$ の連続切片を各々 4 枚づつ作 製し, 脱パラフィン後, 以下の染色を行なった。 なお，本染色法に関しては，1973年に Jones 之 Reid $^{12)}$ が詳細に報告しており，今回我々もて の方法に順じた.

一染色方法一

染色液は，(1) $1 \%$ 酢酸溶液，及び(2) $0.1 \mathrm{~N}$ 塩 酸溶液に $1 \%$ の割合でアルシアンブルー $8 \mathrm{G} \mathrm{X}$

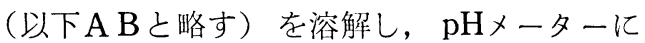

て, (1)は $\mathrm{pH}=2.6 に ，(2) は \mathrm{pH}=1.0$ に補正した ものを使用した。

1） A B - P A S 重染色法

先に用意した切片中 2 枚を，水洗後， $\mathrm{AB}$ (1) $\mathrm{pH}=2.6$ ，(2) $\mathrm{pH}=1.0$ ) でそれぞれ30分間染色 した，(1)は流水で洗浄後，(2)は水洗せずに，切 片の水分を濾紙で吸収乾燥後，(1)(2)共に $0.3 \%$ 炭酸ナトリウムで30分間処理した。洗浄後， 1 $\%$ 過ヨウ素酸中で 5 分間反応させ， 10 分間流水 洗浄し, $25^{\circ} \mathrm{C}$ のッフ試楽に 5 分間入れた。亜 硫酸水で 3 分間づつ 3 回洗ったのち水洗し， マ イヤーのへマトキシリンで核染色を行なった. アルコールで脱水, 透徹後, バルサムで封入し た。

2 ）シアリダーゼ消化法

残り 2 枚の切片を, 蒸留水でよく洗ったの ち, 自然乾燥し, 体積比で蒸留水 9 に対して 1 の割合で $4 \%$ 塩化カルシウム溶液を含む溶媒 中に, 溶媒 4 に対して 1 の制合に $1 \mathrm{U} / \mathrm{ml}$ のシ アリダーゼ (Calbiochem 社) を溶解した。乙 の溶液で 1 枚の切片をおおい，もう 1 枚は溶媒 のみを灌下し， $37^{\circ} \mathrm{C}$ で 12 時間反応させた。洗浄 後, 前述の如く, A B $(\mathrm{pH}=2.6)-\mathrm{PA} \mathrm{S}$ 重 染色を行なった。

表一I．本研究に用いた動物組織中のムコ多糖

\begin{tabular}{|c|c|c|c|c|c|c|}
\hline \multirow[b]{4}{*}{ 組織 } & \multicolumn{3}{|c|}{ ム } & \multicolumn{3}{|c|}{ 糖 } \\
\hline & \multirow{3}{*}{ 中性 } & \multicolumn{2}{|r|}{ 酸 } & \multicolumn{3}{|c|}{ 性 } \\
\hline & & シ & ア & ル & 酸 & \multirow{2}{*}{ 硫酸 } \\
\hline & & \multicolumn{2}{|c|}{ シアリダーゼ感受性 } & \multicolumn{2}{|c|}{ シアリダーゼ抵抗性 } & \\
\hline マウス, 気管腺 & + & \multicolumn{2}{|l|}{+} & \multicolumn{2}{|r|}{-} & - \\
\hline ラット, 舌下腺 & - & \multicolumn{2}{|l|}{-} & \multicolumn{2}{|r|}{+} & - \\
\hline イ 又, 顎下腺 & - & \multicolumn{2}{|l|}{-} & \multicolumn{2}{|r|}{-} & + \\
\hline
\end{tabular}


結

1）ママウス気管腺

$\mathrm{AB}(\mathrm{pH}=2.6)$ - $\mathrm{PAS}$ 染色では，腺細胞の 約半分が青又は青紫に染色し, 残り半分が赤又 は赤紫に染色した. シアリダーゼ消化後 $\mathrm{AB}$ $(\mathrm{pH}=2.6)$-PAS染色执よびAB（ $\mathrm{pH}=1.0 ）$ -PAS染色では, 細胞の大部分が赤又は赤紫に 染色した（図一1）.

2 ) ラット舌下腺

$\mathrm{AB}(\mathrm{pH}=2.6)-\mathrm{PAS}$ 打よびシアリダーゼ 消化後 $\mathrm{AB}(\mathrm{pH}=2.6)-\mathrm{PAS}$ 染色では，大部 分の腺細胞が青又は青紫に染色したが，AB $(\mathrm{pH}=1.0)-\mathrm{PAS}$ 染色では, その染色性が失 われ，赤又は赤紫に染色した（図一2).

3 ）イ又䫟下腺

$\mathrm{AB}(\mathrm{pH}=2.6)-\mathrm{PAS}$, シアリダーゼ消化後 $\mathrm{AB}(\mathrm{pH}=2.6)-\mathrm{PAS}, \mathrm{AB}(\mathrm{pH}=1.0)-\mathrm{PA}$ Sいずれにおいてす，大部分の腺細胞は青又は 青紫に染色した（図一3）.

以上をまとめると表一 2 の如くなる. $\mathrm{AB}$ $(\mathrm{pH}=2.6)-\mathrm{PAS}$ 染色では，マウス気管腺の 約半分, ラット舌下腺, イヌ顎下腺が青染し,

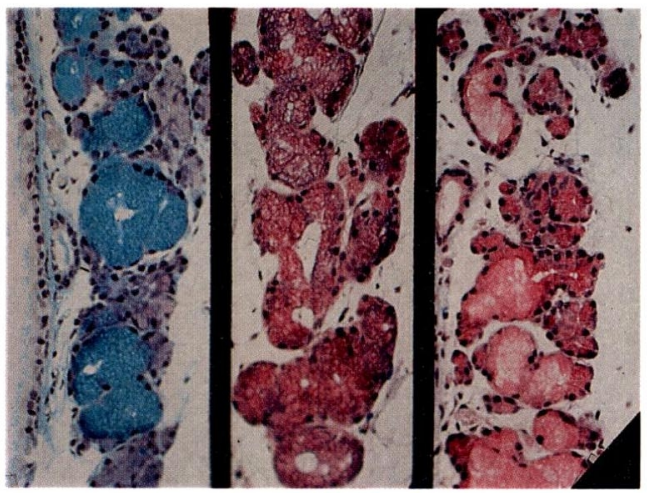

図 I マウス気管腺 $\times 100$
果

マウス気管腺の残り半分が赤染した。 シアリダ 一ゼ消化後 $\mathrm{AB} （ \mathrm{pH}=2.6 ）$ - PAS染色では， ラット舌下腺イヌ顎下腺は青染したが，マウス 気管腺は全て赤染した。 $\mathrm{AB}(\mathrm{pH}=1.0)-\mathrm{PAS}$ 染色では，イ又顎下腺は青染したがマウス気管 腺，ラット舌下腺は赤染した.

なお，シアリダーゼ溶媒のみにて反灾させた 切片に氺いては, $\mathrm{AB}(\mathrm{pH}=2.6)-\mathrm{PAS}$ 染色 と同様の結果を示した。

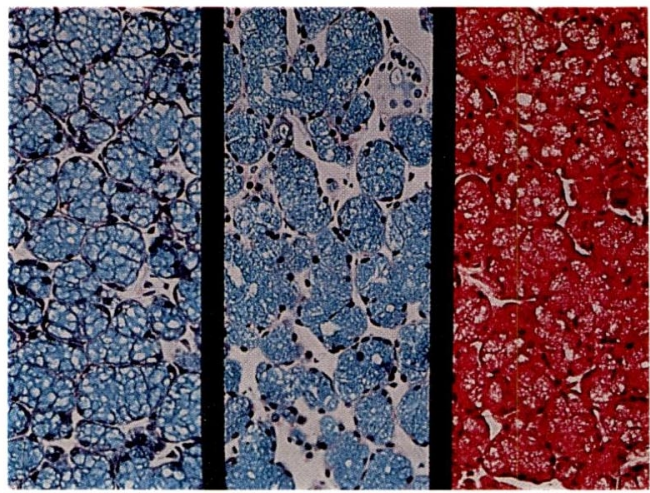

図 2 ラット舌下腺 $\times 100$

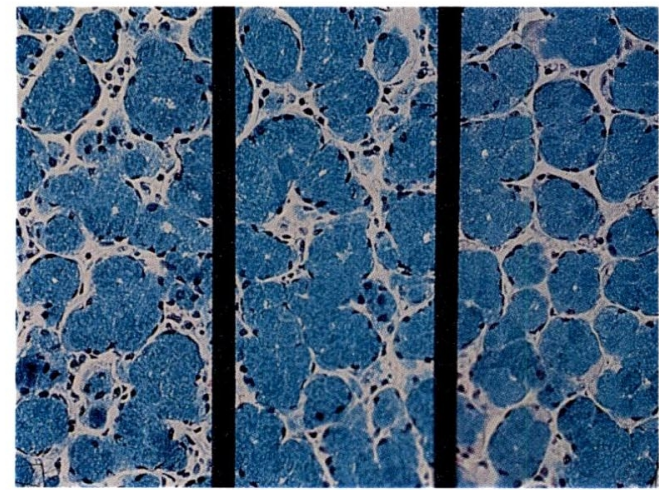

図 3 犬頻下腺 $\times 100$ 
表一2．動物組織における異なったpH下のA B - P A S 重染色結果

\begin{tabular}{|c|c|c|c|}
\hline & マウス気管腺 & ラット舌下腺 & イヌ顎下腺 \\
\hline (1) A B $(\mathrm{pH}=2.6)-\mathrm{PAS}$ & 青 & 青 & 青 \\
\hline $\begin{array}{l}\text { (2) Sialidase- } \\
\text { A B }(\mathrm{pH}=2.6)-\mathrm{PAS}\end{array}$ & 赤 & 青 & 青 \\
\hline (3) A B $(\mathrm{pH}=1.0)-\mathrm{PAS}$ & 赤 & 赤 & 青 \\
\hline 同定された酸性ムコ多糖 & $\begin{array}{l}\text { シアリダーゼ } \\
\text { 感受性 } \\
\text { シアル酸ムコ多糖 }\end{array}$ & $\begin{array}{l}\text { シアリダーゼ } \\
\text { 抵抗性 } \\
\text { シアル酸ムコ多糖 }\end{array}$ & 硫酸ムコ多糖 \\
\hline
\end{tabular}

考

ムコ多糖は，アミノ糖を含む多糖類の総称 で，各種動物組織からみいだされている。 ヒト 生体内にも広く分布し，大別して，結合組織の 基質成分として存在する「狭義のムコ多糖」 と, 結合組織にも存在するが, 細胞の各種の 膜, 粘膜粘液, 血液, 乇の他の体液等に存在す る「糖タンパク」の 2 つがあり, 両者はかなり 異なった役割を果たしている77. 「狭義のムコ 多糖」は，主に組織の構築物質として形態形成 にあずかり, 又, 細胞外液の容量およびイオン を調節する事によって細胞環境の定常性保持に 働く. 一方, 「糖タンパク」は, 潤滑油的働 き，および組織や体表面の保護等といった機能 をもつと言われている。今回我々は，両者のう ち，「糖タンパク」を資料として研究をすすめ た為，本文中の「ムコ多糖」は「糖タンパク」 を表わすものとして理解されたい.

ムコ多糖は，組織において，タンパクと結合 して存在する。タンパク core に結合する単糖 としては，アミノ糖として，D一グルコサミン と D一ガラクトサミンがあり，他に，D一グル クロン酸や $\mathrm{L}$ 一イズロン酸等のウロン酸や， D 一ガラクトース, D一グルコース, L一フコー ス等の中性等がある ${ }^{8)}$. ムコ多糖の構成成分亡 しては，乙の他に，カルボキシル基や硫酸基， アセチル基等の官能基む重要である。乙れら官 能基のうち, 特にカルボキシル基や硫酸基等の

\section{察}

酸性基を持つか否かによりムコ多糖は大別さ れ，分子中に酸性基をむつものを酸性ムコ多 糖，乙れらを含まないものを中性ムコ多糖とよ ぶ. 更に酸性ムコ多糖の中で，特にカルボキシ ル基（- $\mathrm{COOH})$ をむつものをシアル酸ムコ多 糖，硫酸基（- $\mathrm{SO}_{3} \mathrm{H} ）$ をもつものを硫酸ムコ 多糖とよぶ。なお，現在までにわかっている範 囲では，酸性ムコ多糖の大部分は，シアル酸ム コ多糖之硫酸ムコ多糖で占められると考えられ

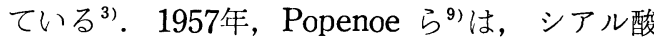
ムコ多糖がシアリダーゼ酵素により選択的に消 化され，他のムコ多糖加ら区別される事を報告 した，ところが，その後の研究により，シアル 酸ムコ多糖の中には，シアリダーゼによって消 化されるもの之，消化されないむのの二つがあ る事が判明した ${ }^{5)}$ ，以上を Jones は，図一4の 如くま之めだ!。すなわち，ムコ多糖は，酸

\section{ムコ多糖}

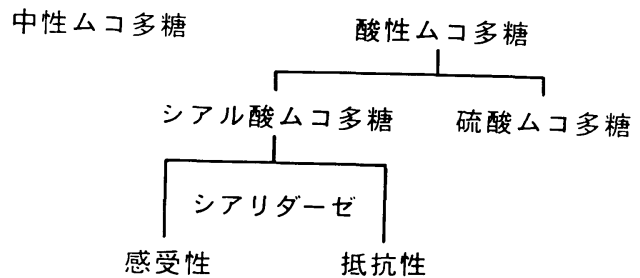

図 4 ムコ多糖の分類 
性基の有無により，酸性ムコ多糖と中性ムコ多 糖とに大別され，酸性ムコ多糖には，シアル酸 ムコ多糖と硫酸ムコ多糖があり, 更に前者に は, シアリダーゼ感受性のもの之抵抗性のもの とが含まれる．1960年，Lison は，「多糖類の 組織化学的研究に利用しうる反応として，そ れまでに発表されていた様々の反応を，反応に 関係あると考えられる基，あるいは，一般物理 特性に従って, 表一 3 の如く分類した ${ }^{11)}$ 。組織 化学の発展によりムコ多糖の分類は, Lison の 頃とは異なっている。しかし，現在なお，表一 3 の反応の多くは，ムコ多糖の証明および鑑別 の基礎をなしていると考えられる.

Periodic Acid-Sciff（以下PAS）反応は， 多糖類一般の染色で，その原理は，分子中の $1 ， 2$ グリコール (- $\mathrm{CHOH} \cdot \mathrm{HOHC}-)$ を過 ヨウ素酸で酸化し，ジアルデヒド（-CHO • OHC-）とし，乙れをシッフ試楽で呈色，証明 するものである．乙の際，過ヨウ素酸は， 1 ， 2 グリコールの他に，その水酸基 $(-\mathrm{OH})$ をア
ミノ基，又はアルキルアミノ基で置換したもの $\left(-\mathrm{CHOH} \cdot \mathrm{CHNH}_{2}{ }^{-},-\mathrm{CHOH} \cdot \mathrm{CHN}<\mathrm{R}_{-}^{-}\right)$ および，酸化型の $(-\mathrm{CHOH} \cdot \mathrm{CHCO}-)$ など とも反応し，ジアルデヒドを形成すると言われ ている，乙の反応により，グリコーゲン，中性 ムコ多糖，酸性ムコ多糖，および糖脂質が赤又 は赤紫に染色する，ただし，酸性ムコ多糖にお いては，分子中に，1，2 グリコール基を有す るにもかかわらず，その周囲に多くの酸性基が 存在して頉滥電している為, 通常のう法では 過ヨウ素酸が作用しにくく，PA S 陰性，ない しは染色不確奏と言われている12).

メタクロマジー，コロイド鉄染色法，アルシ アンブルー染色法は，全て酸性ムコ多糖染色法 で，乙れにより，酸性ムコ多糖は，中性ムコ多 糖から鑑別される ${ }^{13)}$ 。この中で，アルシアンブ ルーは，銅を含むフタロシアニン系の塩基性色

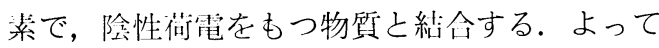
酸性ムコ多糖中の酸性基とも絬合し, 酸性ムコ

表一 3. 多糖類の組織化学的研究に利用しうる反応の瞥見

1 : vic-glicol (- $\mathrm{CHOH}-\mathrm{CHOH}-)$ およびこの近縁群の存在に基づく反応
A. 過沃素酸 Schiff の反応 (PAS)
B. pb tetraacetate-Schiff およびその他の酸化-Schiff の反応
C. 酸化後, Schiff 以外の試薬を用いる反応
D. Acetylation 或いは benzolation による封鎖

2 : 酸性群（sulfuric ester および carbonyl ester）の存在に基づき, 酸性多糖類と中性多糖類とを識別し うる反応

E. メタクロマジー

F．鉄の捕捉反応（Hale）およびその他

G. 好塩基性および見かけ上の等電点の決定

H. Methylation による $-\mathrm{COOH}$ の封鎖, および desulfatation

3. アルコール群 $(-\mathrm{OH})$ の反応

I. Sulfuric esterification

4. 指示染色

$\mathrm{J}$, Alcian blue および Astra blue

K. Aldehyde-fuchsin

5 : 酵素的消化の方法

L． 単純多糖類と加水分解する䣲素 (amylase)

M. 粘液多糖類および粘液蛋白を加水分解する醉素 
多糖は青染する。乙の方法は，ムコ多糖分子中 の酸性基を利用して, 酸性ムコ多糖を証明する 方法であるが，ての場合，酸性ムコ多糖全てが 同様に染色され，シアル酸ムコ多糖と硫酸ムコ 多糖を区別する事はできない，そこで，硫酸ム コ多糖のみ選択的に染色する才法が考案され た. アルデヒドフクシンノアルシアンブルー 法, 硫酸アルミニウム溶液中のアルシアンブル 一法, High Iron Diamin 染色法等がこの中に 含まれる ${ }^{10)}$. 又，放射性同位元素を用いて硫 酸ムコ多糖を検出する方法も行なわれた. 更 に, $80^{\circ} \mathrm{C}$ の $0.1 \mathrm{~N}$ 硫酸でムコ多糖を処理すると, シアル酸ムコ多糖のみ除去される事より ${ }^{14)}$ ，乙 の酸加水分解にアルシアンブルー染色を併用し た方法が，シアル酸ムコ多糖，硫酸ムコ多糖の 鑑別に用いられている。しかし，乙れらの法 は，いずれも非常に複雑である。そこで, 1973 年, Jones と Reid は, アルシアンブルー染色 液の $\mathrm{pH}$ を変える事により, シアル酸ムコ多糖 之硫酸ムコ多糖の染め分けが可能である事をみ いだし，本法にシアリダーゼ消化法を加えた才 法により，ムコ多糖の鑑別が可能である事を報 毕した ${ }^{1)}$. 今回, 我々は, 組織中のムコ多糖が 既に同定されている動物を用いて, Jones と Reidの染色法の有用性を検討した。

結果に示した如く, $\mathrm{AB}(\mathrm{pH}=2.6)-\mathrm{PAS}$ 染色では，マウス気管腺の一部，ラット舌下 腺, イヌ顎下腺の酸性ムコ多糖が青染し, マ
ウス気管腺の残り半分を占める中性ムコ多糖 が赤染した。 シアリダーゼ消化後 $\mathrm{AB}(\mathrm{pH}=$ 2.6）-PAS染色では，ラット舌下腺のシアリ ダーゼ抵抗性シアル酸ムコ多糖，およびイ又顎 下腺り硫酸ムコ多糖は青染したが，マウス気管 腺のシアリダーゼ感受性シアル酸ムコ多糖は $\mathrm{A}$ $\mathrm{B}$ に反応せず，赤染した。 $\mathrm{AB}(\mathrm{pH}=1.0)-$ PASでは，イヌ顎下腺の硫酸ムコ多糖のみ青 染したが，マウス気管腺，ラット舌下腺のシア ル酸ムコ多糖は赤染した（表一2）。すなわ ち, $\mathrm{pH}=2.6$ のアルシアンブルーは， シアル酸 ムコ多糖, 硫酸ムコ多糖いずれの酸性基にも親 和性があり, $\mathrm{AB}(\mathrm{pH}=2.6) \mathrm{PAS}$ 一染色により， 酸性ムコ多糖は全て青染したが，中性ムコ多糖 はA Bに親和性なく P A S 陽性で赤染した。 $\mathrm{pH}=1.0$ のアルシアンブルーは, 硫酸ムコ多糖 等の強酸性の酸性基をもつムコ多糖之は反応す るが，シアル酸ムコ多糖等の弱酸性の酸性基を もつムコ多糖とは反心しない. よって, $\mathrm{AB}(\mathrm{pH}$ =1.0）-PAS染色では，硫酸ムコ多糖は青染 したが，シアル酸ムコ多糖，中性ムコ多糖は赤 染した。シアリダーゼ消化後 $\mathrm{AB}(\mathrm{pH}=2.6)-$ PAS染やでは，シアリダーゼ抵抗性シアル酸ム コ多糖，硫酸ムコ多糖は，シアリダーゼの影響 を受けず青染したが，シアリダーゼ感受性シア ル酸ムコ多糖は，酵素反応でA B に対する染色 性を失ない赤染した，以上をまとめたのが表一 4 である. $\mathrm{AB}(\mathrm{pH}=2.6)-\mathrm{PAS}$ 染色では, 全

表一 4 . 異なったpH下のA B - P A S 重染色法によるムコ多糖類の鑑別

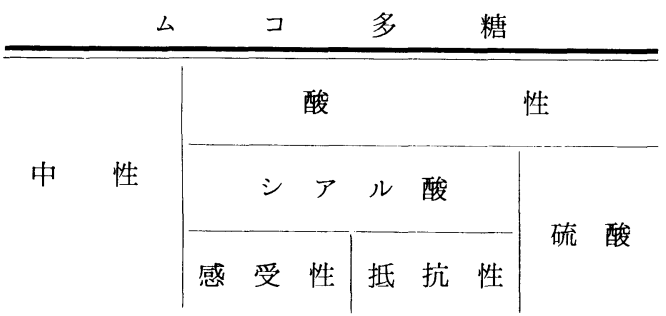

$\mathrm{AB}(\mathrm{pH}=2.6)-\mathrm{PAS}$

Sialidase-

$\leftarrow$ 赤 + 赤紫 $\rightarrow \longleftarrow$ 青 + 青紫 $\longrightarrow$

$\mathrm{AB}(\mathrm{pH}=2.6)$ - P A S

$\mathrm{AB}(\mathrm{pH}=1.0)-\mathrm{PAS} \leftarrow$ 赤十赤紫 $\longrightarrow \leftarrow$ 青十青紫 $\rightarrow$ 
ての酸性ムコ多糖が青染し, 中性ムコ多糖は赤 染した. シアリダーゼ消化後, $\mathrm{AB}(\mathrm{pH}=2.6)$ -PAS染色では，シアリダーゼ抵抗性シアル酸 ムコ多糖と硫酸ムコ多糖は青染したが，シアリ ダーゼ感受性シアル酸ムコ多糖は赤染した。 $\mathrm{AB}(\mathrm{pH}=1.0)-\mathrm{PAS}$ 染色では, 硫酸ムコ多糖

\section{結 語}

シアリダーゼ感受性シアル酸ムコ多糖と，中性ムコ多糖を主に産生するマウス気管腺，シアリダ 一ゼ抵抗性シアル酸ムコ多糖を産生するラット舌下腺，硫酸ムコ多糖を産生するイ又顎下腺を用い て，異なった $\mathrm{pH}$ 下の $\mathrm{AB}-\mathrm{PAS}$ 重染色法，およびシアリダーゼ消化法を施行し，以下の事を確認 した.

1) $\mathrm{AB}(\mathrm{pH}=2.6)-\mathrm{PAS}$ 重染色法で, 酸性ムコ多糖は青染し, 中性ムコ多糖は赤染する.

2 ) シアリダーゼ消化後 $\mathrm{AB}(\mathrm{pH}=2.6)-\mathrm{PAS}$ 染色で，シアリダーゼ抵抗性シアル酸ムコ多糖 と, 硫酸ムコ多糖は青染するが, シアリダーゼ感受性シアル酸ムコ多糖, 中性ムコ多糖は赤染す る.

$3) \mathrm{AB}(\mathrm{pH}=1.0)$ - $\mathrm{PAS}$ 染色で，硫酸ムコ多糖は青染するが，シアル酸ムコ多糖，中性ムコ多 糖は赤染する.

以上より，本法が，ムコ多糖の鑑別に有効かつ簡便である事が確かめられた。

稿を終えるにあたり，A B一P A S染色について，御指導，御教示をいただいた北海道大学免疫科学研究所細 胞免疫部門奥山春枝教授に深く感謝致します.

なお，本論文の要旨は，第21回鼻副鼻腔学会にて口演した。

\section{參考文献}

1) Jones, R, and Reid, L.: The effect of $\mathrm{pH}$ on Alcian Blue staining of epithelial acid glycoproteins. I. Sialomucins and sulphomucins. Histochemical J 5: 9 18, 1973.

2 ) Jones, R. and Reid, L.: The effect of $\mathrm{pH}$ on Alcian Blue staining of epithelial acid glycoproteins. II. Human bronchial submucosal gland. Histochemical J $5: 19 \sim 27$, 1978.

3 ) Jones, R.: The glycoproteins of secretory cells in airway epithelium. Ciba Found Symp $54:$ 175 188, 1978.

4 ) McCarthy, C. and Reid, L. : Acid mucopolysaccharide in the bronchial tree in the mouse and rat. Q J Exp Physiol $49: 81 \sim 84$, 1964.

$5)$ Spicer, S.S. and Warren, L. : The histoche- mistry of sialic acid containing mucoproteins. J Histochem Cytochem $8: 135 \sim 137$, 1960.

6 ) Butler, M.G. : A new method of hydrolysis for the identification of acid glycoprotein. Medical Laboratory Technology 30:105 112, 1973.

7 ) 吉沢善作：ムコ多糖の構造 と機能. 臨床病理 XXIV II:865 871, 1976.

8 ）瀬野信子：酸性ムコ多糖の基礎と臨床一その 1 基礎 酸性ムコ多糖の構造の多様性. リウマチ 17( 3 ) : 359 368, 1977.

$9)$ Popenoe, E.A. and Drew, R.M. : The action of an enzyme of Clostridium perfringens on orosomucoid. J Biol Chem 228:673 683, 1975.

10) Lamb, D. and Reid, L. : Histochemical types 
of acidic glycoprotein produced by mucous cells of the tracheobronchial glands in man. J Path 98( 4 ): 213 229, 1969.

11) Lison, L. : 組織化学および細胞化学, 今泉正訳 :361 405, 白水社, 東京 1960 .

12）金子 仁：カラーアトラス病理組織標本. 染色法 シリーズ, 1980.

13）影山圭三, 渡辺陽之輔 : 病理組織標本の作り方. 医学書院 1957.
14) Gibbons, R.A. : The sensitivity of the neuraminosidic lincage in mucosubstances towards neuraminidase. Biochem J $89: 380 \sim 391$, 1963.

$$
\begin{aligned}
& \text { 原稿到着：昭和 } 56 \text { 年 } 6 \text { 月 } 15 \text { 日 } \\
& \text { 別刷請求先 : 堀 みどり } \\
& \text { †514 津市江戸橋 } 2-174 \\
& \text { 三重大学医学部耳鼻咽喉科学教室 }
\end{aligned}
$$

